\title{
A simple marker in supporting the diagnosis of the incomplete Kawasaki disease: Red cell distribution width
}

\section{İnkomplet Kawasaki hastalığı tanısını destekleyen basit bir belirteç: eritrosit dağılım genişliği}

Mehmet Kucuk, Cem Karadeniz, Rahmi Ozdemir, Timur Meșe

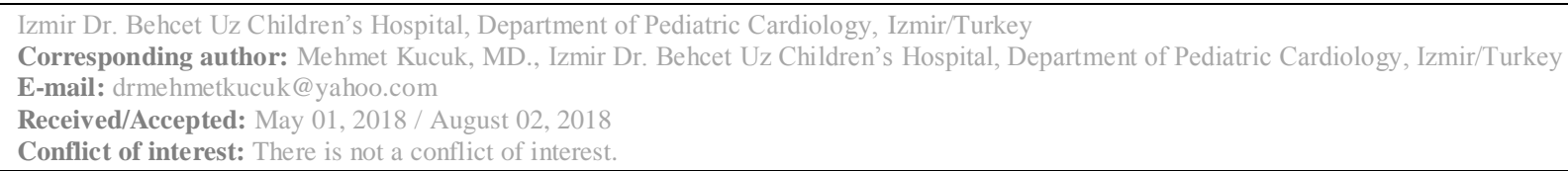

\section{SUMMARY}

Objective: To assess whether red cell distribution width (RDW) would be a useful laboratory marker for Kawasaki disease (KD), particularly its incomplete form (iKD).

Method: We retrospectively evaluated the medical records of cases diagnosed with Kawasaki disease.

Results: The number of the cases with KD and controls were 67 and 69, respectively. RDW values were significantly higher in patients with KD compared to controls. When clinical and laboratory findings of complete and incomplete Kawasaki disease patients were compared, age at diagnosis was significantly lower and RDW values were significantly higher in patients with iKD.

Conclusions: Our results showed that elevated RDW levels can be used as a simple, inexpensive laboratory marker in supporting the diagnosis of iKD.

Keywords: Coronary artery lesions, children, incomplete Kawasaki disese, Kawasaki disease, red cell distribution width

\section{ÖZET}

Amaç: Kawasaki Hastalığında ve özellikle inkomplet formunda, eritrosit dağılım genişliğinin (EDG) faydalı bir laboratuar belirteci olup olmadığını araştırmak.

Yöntem: Hastanemizde Kawasaki Hastalığı tanısı almış çocuk hastalarımızın dosyaları retrospektif olarak incelendi.

Bulgular: Çalışmamıza, Kawasaki Hastalığı olan 67 hasta ve 69 kontrol vaka alındı. EDG değerleri Kawasaki hastalarında, kontrol vakalarıyla karşılaştıııldığında anlamlı olarak daha yüksek bulundu. Komplet ve inkomplet Kawasaki hastalarının klinik ve laboratuar bulguları karşılaş̧ırıldığında: İnkomplet Kawasaki hastalarında, tanı anındaki yaş anlamlı olarak daha düşük, EDG ise anlamlı olarak daha yüksek saptandı.

Sonuç: Sonuçlarımız EDG’nin inkomplet Kawasaki Hastalığı tanısını desteklemede basit ve ucuz bir belirteç olabileceğini göstermektedir

Anahtar sözcükler: Koroner arter lezyonları, çocuk, inkomplet Kawasaki Hastalığı, Kawasaki Hastalı̆̆ı, Eritrosit dağılım genişliği 


\section{INTRODUCTION}

Kawasaki disease (KD) is an acute systemic selflimited vasculitis affecting multiple organs and tissues. ${ }^{1}$ Coronary artery involvement is the most important and life-threatening complication that may lead to myocardial ischemia, infarction, and even sudden death in untreated individuals. Children between 6 months and 5 years of age are more susceptible to $\mathrm{KD}^{2,3}$

Because of lack of specific laboratory tests, accurate diagnosis is set according to the clinical findings. In addition to fever lasting longer than 5 days at least four of the following principal findings are needed for diagnosis: change in extremities, polymorphous exanthema, bilateral non-purulent conjunctivitis, changes in lips and oral cavity, and usually unilateral cervical lymphadenopathy. ${ }^{1}$ The patients who have prolonged fever but do not fulfill above mentioned criteria are called as incomplete $\mathrm{KD}$ (iKD) and it is more common among young infants than older children. ${ }^{1}$ These patients more likely to develop coronary artery aneurysms. Early diagnosis and treatment are crucial to prevent adverse outcomes related to coronary artery lesions (CALs). ${ }^{1,4}$ Despite supplementary laboratory findings proposed by American Heart Association (AHA), ${ }^{1}$ the diagnosis is still challenging and further laboratory tests are required for accurate diagnosis of $\mathrm{KD}$.

Red blood cell distribution width (RDW) is a parameter measured in complete blood count (CBC) that reflects the variability in the sizes of circulating erythrocytes. In routine clinical practice it is used for differential diagnosis of anemia. However, it was also found to be increased in inflammatory conditions and recent studies have shown that RDW is strongly correlated with adverse outcomes in patients with heart failure, myocardial infarction, pulmonary embolism, pulmonary hypertension, chronic obstructive pulmonary disease, migraine, and critical illnesses. ${ }^{5-11}$

In this study, we aimed to assess whether RDW would be a useful supplementary laboratory marker to diagnose KD, particularly its incomplete form.

\section{MATERIAL AND METHODS}

\section{Patients}

We retrospectively evaluated the medical records of all the cases diagnosed with Kawasaki disease between 2006 to 2012 from Izmir Dr Behcet Uz
Children's Hospital. The patients were divided into two groups consisting of complete and incomplete forms of $\mathrm{KD}$. Complete $\mathrm{KD}$ was determined according to previously reported criteria. ${ }^{1}$ The patients who had prolonged fever and 2 or 3 clinical criteria together with at least three supplementary laboratory findings or echocardiographic coronary artery abnormalities were diagnosed to have incomplete $\mathrm{KD} .{ }^{1}$ The complete blood counts of sex-age matched children with fever, diagnosed with flu due to influenza, were used as controls. Patients with previous history of anemia treated with any medications or erythrocyte transfusion or known hematological diseases such as thalassemia trait, hemolytic anemia that could affect plasma RDW values were excluded from the study. The study was approved by the ethical committee of our institution.

\section{Echocardiography}

Vivid 3 Pro Ultrasound System (GE Medical Systems, NE, USA) with 3 and $5 \mathrm{MHz}$ transducers was used in order to evaluate coronary artery lesions by 2-dimensional echocardiography before intravenous immunoglobulin administration. CALs were defined as enlargement of coronary arteries at least two standard deviation above the mean adjusted to body surface area. CALs include dilatation and/or ectasia and aneurysm.

\section{Laboratory data}

Complete blood counts of patients and control subjects including white blood cell (WBC), neutrophil and lymphocyte counts, hemoglobin levels, mean corpuscular volume (MCV), RDW, platelets, mean platelet volume (MPV), platelet distribution width (PDW), erythrocyte sedimentation rate (ESR), and C-reactive protein (CRP) values were obtained from a computerized patient database.

\section{Statistical analysis}

Data was analyzed and processed with SPSS 18.0 statistical package programme (SPSS Inc., Chicago, Illinois, USA). The distribution pattern of data was assessed by the Kolmogrov-Smirnow test. Quantitative variables were demonstrated as mean \pm standard deviation for normally distributed data or as median and interquartile ranges for the others. The Chi-square test or Fisher's exact test were used to compare the qualitative data. The differences between the quantitative groups with normal distribution were evaluated with Student's t-test. The Mann- 
Whitney $U$ test was used for abnormally distributed data. The logistic regression test was used for determining the cause and effect relationship the diagnosis of incomplete $\mathrm{KD}$ and the laboratory parameters. ROC (Received Operating Curve) was obtained to detect significant predictor cut-off values for the diagnosis of incomplete KD. $\mathrm{P}$ value of $<0.05$ was considered as statistically significant.

\section{RESULTS}

The number of the cases with $\mathrm{KD}$ and controls were 67 and 69, respectively. Forty-three of the patients were diagnosed to have cKD. Clinical characteristics of the patients with $\mathrm{KD}$ and controls were shown in Table 1 . The median age of the patients at admission was 35 months. The groups were similar in terms of age and gender ( $p>0.05)$. WBC, neutrophil, platelet counts, and RDW values were significantly higher and hemoglobin and MPV levels were statistically lower in patients with KD compared to controls $(\mathrm{p}<0.01)$. There was no significant difference between the groups in terms of lymphocyte count.

Table 1: The comparison of the characteristics of patients and controls

\begin{tabular}{|c|c|c|c|}
\hline & KD (cKD and iKD, n=67) & Controls $(n=69)$ & P value \\
\hline Age at diagnosis (months) ${ }^{\mathrm{a}}$ & $35(44)$ & $40(56)$ & 0.26 \\
\hline Sex (male/female) $(n)$ & $44 / 23$ & $44 / 25$ & 0.81 \\
\hline WBC count $\left(\mathrm{X} 10^{3} / \mu \mathrm{l}\right) \mathrm{b}$ & $13.1 \pm 5.1$ & $8.4 \pm 2.3$ & $<0.01$ \\
\hline Neutrophil count $\left(X^{3} 10^{3} / \mu 1\right)^{a}$ & $6.7(3.7)$ & $3.7(1.2)$ & $<0.01$ \\
\hline Lymphocyte count $\left(\mathrm{X} 10^{3} / \mu \mathrm{l}\right)^{\mathrm{b}}$ & $4.0 \pm 1.7$ & $4.3 \pm 1.5$ & 0.41 \\
\hline Hemoglobin $(\mathrm{gr} / \mathrm{dl})^{\mathrm{a}}$ & $10.7(1.1)$ & $11.9(1.3)$ & $<0.01$ \\
\hline $\operatorname{MCV}(\mathrm{fl})^{\mathrm{b}}$ & $79.8 \pm 3.8$ & $78 \pm 4.9$ & $<0.01$ \\
\hline RDW $(\%)^{\mathrm{a}}$ & $14.3(1.8)$ & $13.4(1.8)$ & $<0.01$ \\
\hline 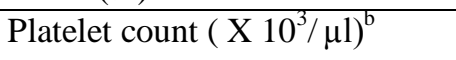 & $456(383)$ & $298(113)$ & $<0.01$ \\
\hline MPV (fl) ${ }^{b}$ & $8.1 \pm 0.9$ & $9.4 \pm 1.1$ & $<0.01$ \\
\hline $\operatorname{PDW}(\%)^{\mathrm{a}}$ & $10.5(3.5)$ & $10.7(1.8)$ & 0.83 \\
\hline
\end{tabular}

KD: Kawasaki disease, cKD: complete KD, iKD: incomplete KD, WBC: white blood cell, MCV: mean corpuscular volume, MPV: mean platelet volume, PDW: platelet distribution width, RDW: red blood cell distribution width

${ }^{\mathrm{a}}$ : Data presented as median (interquartile range) ; ${ }^{\mathrm{b}}$ : Data presented as mean \pm standard deviation

Forty-three cases had complete and 24 cases had incomplete KD according to clinical findings. The numbers of the patients with coronary involvement in those groups were 13 and 10, respectively. When clinical and laboratory findings of complete and incomplete Kawasaki disease patients were compared each other, age at diagnosis was significantly lower and RDW levels were significantly higher in patients with $\mathrm{iKD}$ $(\mathrm{p}<0.01)$.

A RDW value above $13.4 \%$ predicted the diagnosis of incomplete $\mathrm{KD}$, with a sensitivity of
$89 \%$ and a specifity of $37 \%$ (Figure 1). Analysis of the ROC curve for the RDW showed an AUC of 0.67 (p:0.004) (95\% CI 55-79). Moreover, among the significant variables determined in the incomplete KD group, only RDW was found to be an independent predictor for the diagnosis of incomplete $\mathrm{KD}$ in regression analysis $(\mathrm{OR}=1,5$; 95\% CI: 1.2-2,1; p: 0.009) (Figure 2). No other difference could be found in terms of sex, WBC, neutrophil, lymphocyte, and platelet counts and MPV, ESR, and CRP levels (p>0.05) (Table 2). 
Table 2: The comparison of the features of the cases with complete and incomplete Kawasaki disease

\begin{tabular}{|c|c|c|c|}
\hline & Complete KD $(n=43)$ & Incomplete KD $(n=24)$ & P value \\
\hline Age at diagnosis (months) & $51 \pm 33.5$ & $31 \pm 20$ & $<0.01$ \\
\hline Sex $($ male/female $)(n)$ & $28 / 15$ & $16 / 8$ & 0.89 \\
\hline WBC count $\left(\mathrm{X} 10^{3} / \mu \mathrm{l}\right)^{\mathrm{b}}$ & $13.3 \pm 5.2$ & $12.6 \pm 4.9$ & 0.58 \\
\hline Neutrophil count $\left(X_{10}^{3} / \mu 1\right)^{a}$ & $6.7(4)$ & $6.4(3.1)$ & 0.08 \\
\hline Lymphocyte count $\left(\mathrm{X} 10^{3} / \mu \mathrm{l}\right)^{\mathrm{a}}$ & $4.0(2.8)$ & $3.8(2.5)$ & 0.51 \\
\hline Hemoglobin $(\mathrm{gr} / \mathrm{dl})^{\mathrm{a}}$ & $10.7(1.1)$ & $10.6(1.5)$ & 0.62 \\
\hline $\operatorname{MCV}(f 1)^{b}$ & $80.9 \pm 3.0$ & $77.7 \pm 4.3$ & $<0.01$ \\
\hline $\mathrm{RDW}(\%)^{\mathrm{b}}$ & $14.0 \pm 1.3$ & $15.4 \pm 1.7$ & $<0.01$ \\
\hline 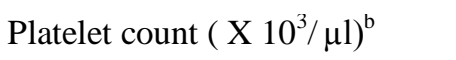 & $514 \pm 263$ & $531 \pm 237$ & 0.78 \\
\hline $\operatorname{MPV}(f l)^{b}$ & $8.1 \pm 0.9$ & $8.0 \pm 1.0$ & 0.55 \\
\hline $\operatorname{PDW}(\%)^{\mathrm{a}}$ & $10.5(3.6)$ & $10.3(3.9)$ & 0.74 \\
\hline $\mathrm{CRP}(\mathrm{mg} / \mathrm{dl})^{\mathrm{a}}$ & $2.5(4.7)$ & $2.9(4)$ & 0.15 \\
\hline $\operatorname{ESR}(\mathrm{mm} / \text { hour })^{\mathrm{b}}$ & $83 \pm 34$ & $77 \pm 33$ & 0.48 \\
\hline $\operatorname{CALs}(n)$ & 13 & 10 & 0.34 \\
\hline
\end{tabular}

KD: Kawasaki disease, cKD: complete KD, iKD: incomplete KD, WBC: white blood cell, MCV: mean corpuscular volume, MPV: mean platelet volume, PDW: platelet distribution width, RDW: red blood cell distribution width, CRP: C-reactive protein, ESR: erythrocyte sedimentation rate

${ }^{\mathrm{a}}$ : Data presented as median (interquartile range) $;^{\mathrm{b}}:$ Data presented as mean \pm standard deviation

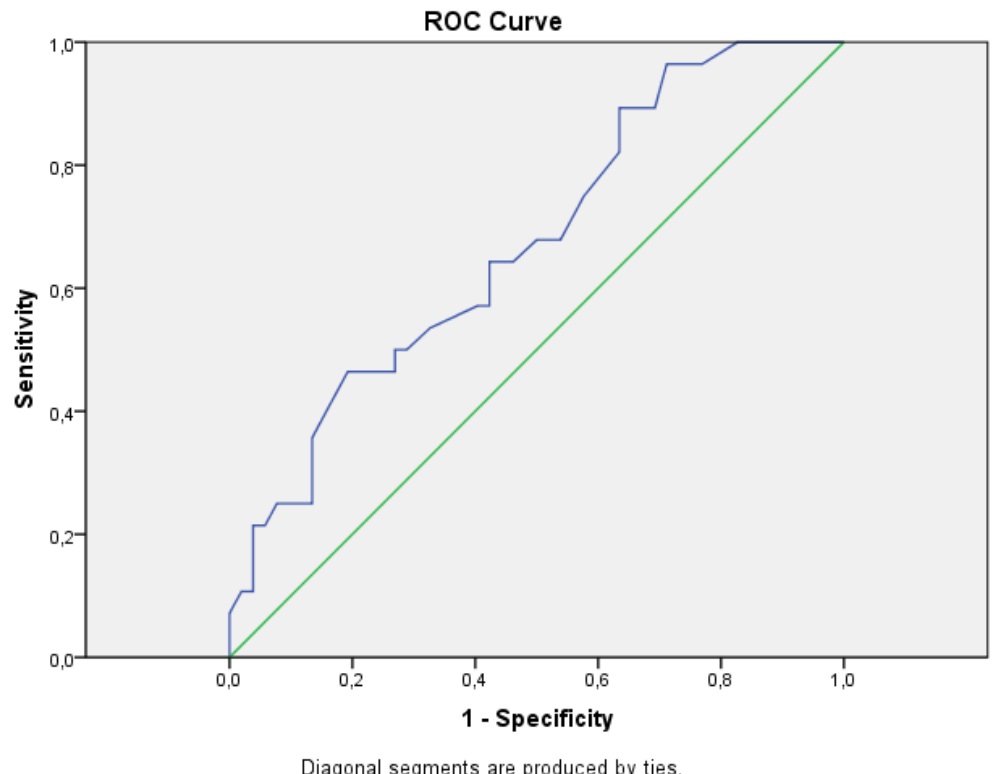

Figure 1: Receiver Operating Curve of the RDW for predicting the diagnosis of incomplete Kawasaki disease. 


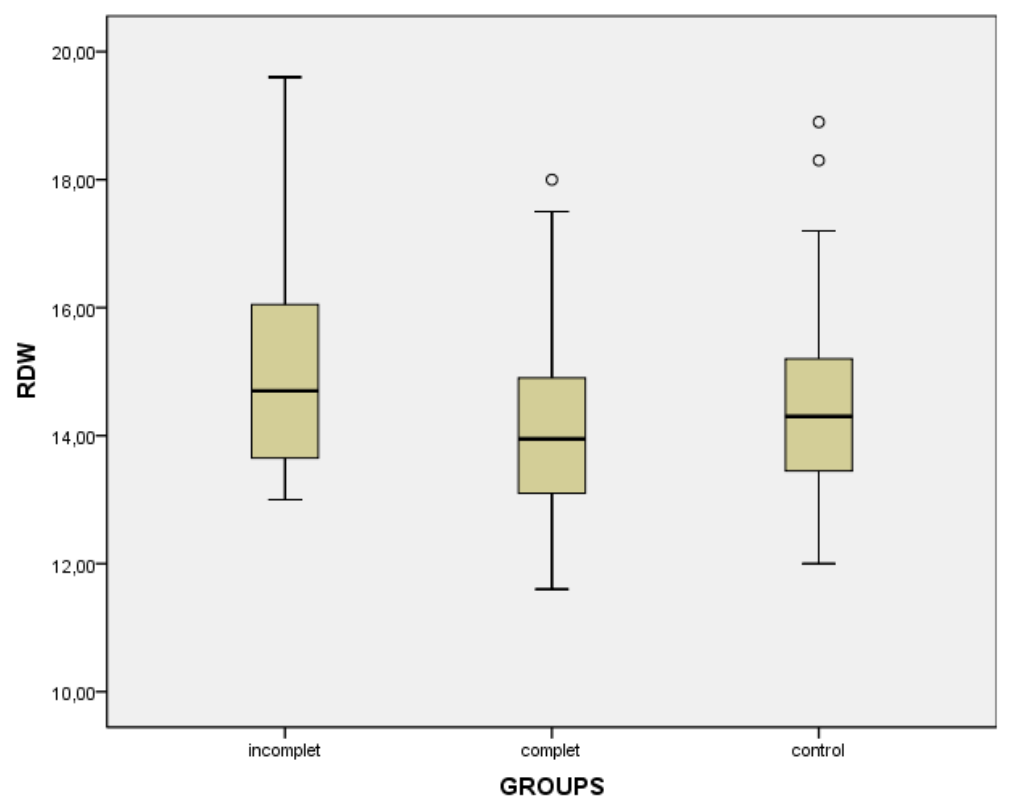

Figure 2: $\quad$ Box-plot graphic showing the distribution of RDW values in incomplete and complete Kawasaki patients and the control group.

\section{DISCUSSION}

Kawasaki disease is an important and potentially life-threatening inflammatory condition, the diagnosis of which is a challenge in the patients with incomplete clinical findings. Despite the recommendations of AHA considerable number of cases remains undiagnosed. ${ }^{1,12}$ Necessity of novel diagnostic tools prompted us to evaluate RDW for the diagnosis and discrimination of clinical subtypes of KD and we found it useful in both situations. To our knowledge, this study is the first to show that RDW could be an independent predictor for the diagnosis of incomplete $\mathrm{KD}$.

Despite KD can easily be confused with other conditions with similar clinical findings such as viral infections (e.g., measles, adenovirus, enterovirus, Epstein-Barr virus), scarlet fever, toxic shock syndrome, juvenile rheumatoid arthritis, and drug reactions, no specific diagnostic laboratory test exists for differentiation of $\mathrm{KD} .{ }^{1}$ The diagnosis of KD can only be made by clinical criteria mentioned above. ${ }^{1}$ Although the disease is generally self-limited, early diagnosis and therapy are very important in some instances in order to prevent life-threatening complications related to CALs. Because the incidence of CALs reduces from $25-30 \%$ to less than $5 \%$ with intravenous immunoglobulin (IVIG) treatment initiated within the first 10 days of disease. ${ }^{1,13}$ As the patients with iKD who do not meet all clinical criteria are at a greater risk for diagnostic delays and development of CALs, some supplemental laboratory findings such as hypoalbuminemia $(<3$ $\mathrm{g} / \mathrm{dl})$, anemia, elevation of alanine aminotransferase, thrombocytosis (after 7 days, $\left.>450000 / \mathrm{mm}^{3}\right)$, leukocytosis $\left(>15000 / \mathrm{mm}^{3}\right)$, and sterile pyuria ( $>10$ white blood cells/high-power field) were recommended by AHA. ${ }^{1}$ However, the diagnosis of $\mathrm{iKD}$ still remains unclear in considerable portion of cases. Therefore, in recent years, some further laboratory markers have been studied in cases with KD including mean platelet volume (MPV) and platelet distribution width (PDW). Liu et al. determined lower MPV and PDW values in KD patients compared to healthy controls and MPV and PDW values of iKD patients were found even lower than the cases with complete diagnostic criteria. ${ }^{14}$ The precise reason of lower MPV levels have not been established yet. It is supposed to be related to intensive consumption of large activated platelets at inflammation sites or excessive production of cytokines which may lead to suppression of the sizes of platelets. ${ }^{15,16} \mathrm{We}$ also observed significantly lower MPV values in KD patients compared to controls. However, in contrast to Liu et al., ${ }^{1}$ no difference was determined in terms of PDW values. We did not find any difference between iKD and complete KD groups by MPV and PDW values as well. 
RDW is a simple biomarker that is routinely reported in complete blood count analysis without additional cost. It is mainly used for differential diagnosis of anemia. Recently reported studies have shown that RDW might be a predictor of some adverse outcomes in patients with heart failure, pulmonary arterial hypertension, pneumonia, myocardial infarction, pulmonary embolism, septic shock, and congenital cardiac surgery. ${ }^{5-8,11,17,18}$ The mechanisms for the elevated RDW in those diseases have not been elucidated yet. Elevated RDW values and anisocytosis may be associated with activation of proinflammatory cytokines such as interleukin (IL)-6, tumor necrosis factor (TNF)- $\alpha$, and IL- $1 \beta$ that can interfere with erythropoietin inducederythropoiesis and decrease the life span of the red blood cells. ${ }^{11,19}$ Besides the inflammation, oxidative stress and activation of neurohormonal pathways are another possible mechanisms that can lead to decrease in half-life and increase in production of red blood cells. ${ }^{11,20}$ The fact that proinflammatory cytokines including IL-1, IL-6, and TNF- $\alpha$ were up-regulated in acute phase of KD might explain why anemia and elevated RDW values were determined in our population. ${ }^{21}$ Adverse outcomes in $\mathrm{KD}$ patients may be associated with more severe inflammation which shows itself with more pronounced elevation in erythrocyte sizes and RDW values.

\section{Limitations of the study}

Retrospective design and relatively small sample size are the main limitations of the present study. Due to the retrospective design of this study, we could not evaluate the vitamin $\mathrm{B}_{12}$, folate, iron levels, and nutritional status which are suggested as a potential cause of increased RDW levels. And finally, the diagnosis of CALs in patients with KD was not confirmed by coronary angiography which is the best way for demonstration of CALs.

\section{CONCLUSION}

Our results showed that elevated RDW levels can be used as a simple, inexpensive laboratory marker in supporting the diagnosis of $\mathrm{iKD}$ which is frequently misdiagnosed and associated with coronary involvement. The present study is the first to demonstrate that elevated levels of RDW could be an independent predictor for the diagnosis of $\mathrm{iKD}$. Owing to the retrospective design of our study, further prospective studies with greater number of patients may be helpful to evaluate the clinical significance of elevated RDW values in patients with KD properly.

\section{REFERENCES}

1. Newburger JW, Takahashi M, Gerber MA, et al. Diagnosis, treatment and long-term management of Kawasaki disease: a statement for health professionals from the Committee on Rheumatic Fever, Endocarditis and Kawasaki Disease, Council on Cardiovascular Disease in the Young, American Heart Association. Circulation 2004;110(17), 2747-2771.

2. Huang WC, Huang LM, Chang IS, et al. Epidemiologic features of Kawasaki disease in Taiwan, 20032006. Pediatrics 2009;123(3), 401405.

3. Nakamura Y, Yashiro M, Uehara R, Uehara R, Oki I, Kayaba K, Yanagawa $\mathrm{H}$. Increasing incidence of Kawasaki disease in Japan: nationwide survey. Pediatr Int 2008;50(3), 287-290.

4. Perrin L, Letierce A, Guitton C, Tran TA, Lambert V, Koné-Paut I. Comparative study of complete versus incomplete Kawasaki disease in 59 pediatric patients. Joint Bone Spine 2009;76(5), 481-485.

5. Felker GM, Allen LA, Pocock SJ, et al. Red cell distribution width as a novel prognostic marker in heart failure: data from the CHARM Program and the Duke Databank. $J$ Am Coll Cardiol 2007;50(1), 40-47.

6. Lee JH, Yang DH, Jang SY, et al. Incremental Predictive Value of Red Cell Distribution Width for 12-Month Clinical Outcome After Acute Myocardial Infarction. Clin Cardiol 2013;36(6), 336-341.

7. Ozsu S, Abul Y, Gunaydin S, Orem A, Ozlu T. Prognostic Value of Red Cell Distribution Width in Patients With Pulmonary Embolism. Clin Appl Thromb Hemost 2012;20(4), 365-70.

8. Hampole CV, Mehrotra AK, Thenappan T, Gomberg-Maitland M, Shah SJ. Usefulness of red cell distribution width as a prognostic marker in pulmonary hypertension. Am J Cardiol 2009;104(6), 868-872.

9. Seyhan EC, Ozgul MA, Tutar N, Omür I, Uysal A, Altın S. Red Blood Cell Distribution and Survival in 
Patients with Chronic Obstructive Pulmonary Disease. COPD 2013;10(4), 416-424.

10. Celikbilek A, Zararsiz G, Atalay T, Tanik N. Red cell distribution width in migraine. Int $J$ Lab Hematol 2013;35(6), 620-8.

11. Jo YH, Kim K, Lee JH, et al. Red cell distribution width is a prognostic factor in severe sepsis and septic shock. Am J Emerg Med 2013;31(3), 545-548.

12. Kato H, Ichinose E, Yoshioka F, et al. Fate of coronary aneurysms in Kawasaki disease: serial coronary angiography and long-term follow-up study. Am J Cardiol 1982;49: 1758 1766.

13. Newburger JW, Takahashi M, Beiser AS, et al. A single intravenous infusion of gamma globulin as compared with four infusions in the treatment of acute Kawasaki syndrome. $N$ Engl $J$ Med 1991;324(23), 1633-1639.

14. Liu R, Gao F, Huo J, Yi Q. Study on the relationship between mean platelet volume and platelet distribution width with coronary artery lesion in children with Kawasaki disease. Platelets 2012;23(1), 11-16.

15. Collins CE, Rampton DS, Rogers J, Williams NS. Platelet aggregation and neutrophil sequestration in the mesenteric circulation in inflammatory bowel disease. Eur $J$ Gastroenterol Hepatol 1997;9(12), 1213-1217.

16. Kapsoritakis AN, Koukourakis MI, Sfiridaki A, et al. Mean platelet volume: A useful marker of inflammatory bowel disease activity. Am J Gastroenterol 2001;96:776781.

17. Lee JH, Chung HJ, Kim K, et al. Red cell distribution width as a prognostic marker in patients with communityacquired pneumonia. Am J Emerg Med 2013;31(1):72-79.

18. Massin MM. Relation between red cell distribution width and clinical outcome after surgery for congenital heart disease in children. Pediatr Cardiol 2012;33(7),1021-1025.
19. Scharte M, Fink MP. Red blood cell physiology in critical illness. Crit Care Med 31(12 Suppl), 2003;651657.

20. Ghaffari S. Oxidative stress in the regulation of normal and neoplastic hematopoiesis. Antioxid Redox Signal 2008;10(11), 1923-1940.

21. Barron K, DeCunto C, Montalvo J, Orson F, Lewis D. Abnormalities of immunoregulation in Kawasaki syndrome. $J \quad$ Rheumatol 1988;15(8):1243-1249. 